\title{
Solution-focused Brief Counseling Guidebook: Theoretical Validity and Effectiveness in Reducing Student's Social Anxiety
}

\author{
Wayan Purwani ${ }^{1}$, Kadek Suranata ${ }^{\left.2^{*}\right)}$, Ketut Gading ${ }^{3}$ \\ 1,2,3 Universitas Pendidikan Ganesha \\ *Corresponding author, e-mail: kadek.suranata@undiksha.ac.id
}

Received August 02, 2021; Revised August 31, 2021; Accepted Sept. 20, 2021; Published Online 2021-10-01

\section{Conflict of Interest} Disclosures:

The authors declare that they have no significant competing financial, professional or personal interests that might have influenced the performance or presentation of the work described in this manuscript.

\begin{abstract}
Social anxiety is one of the psychological problems faced by most of students. Several research findings have revealed negative effects that arise due to the high level of social anxiety experienced by students. Based on this phenomenon, schools play a major role in efforts to minimize the level of social anxiety experienced by students through optimizing guidance and counseling services. This research and development aim at testing the acceptability and effectiveness a solution-focused brief counseling guidebook to minimize students' social anxiety. The development procedure using 4D steps, such as, define, design, develop, and dissemination of the product. The amount five judgment involve to validating the contents of guidebook. For the piloting, one group pretest-posttest experimental procedure involves 15 junior high school students. The data analysis for judgments results show that the counseling guidebook developed in this study has a special content validity index (CVI). Based on the results of the piloting study, counseling guidebook a solutionfocused brief counseling guidebook with the miracle question technique was effective in reducing students' social anxiety. The results of this study contribute to the optimization of guidance and counseling services in schools.
\end{abstract}

Keywords: solution-focused brief counseling, social anxiety, R\&D in counseling.

\section{Introduction}

Student life at school cannot be separated from various interactions, both between peers, teachers, and other people in the school environment. In order to create good social interactions, students are often faced with situations to create new relationships or social networks outside their families through adjustment to the school environment, as well as facing challenges in academic achievement (Mitchell, MacInnes, \& Morrison, 2008). When most students are able to face these challenges, it cannot be denied that there are still students who face difficulties both in academic achievement and in interacting with their social environment. This difficulty is often the background for the emergence of psychological problems experienced by students (Brook \& Willoughby, 2015). 
The difficulties experienced by students when doing social interactions with their environment can be caused by various factors. These difficulties can occur because students experience conditions of social anxiety. Social anxiety that occurs in students is still quite high. A study conducted by Vriends, Pfaltz, Novianti, \& Hadiyono (2013) reported that there were still many students in Indonesia who showed quite high symptoms of social anxiety (15.8\%). Several research results have also reported that social anxiety is a problem that often occurs in adolescents (students). Research conducted by Hakami et al. (2018) reported that $25.8 \%$ of 476 students showed symptoms of social anxiety. In line with research conducted by Untari, Bahri, \& Fajriani (2017) reported that there were many phenomena of students showing social anxiety symptoms, such as difficulty speaking in public, not able to adapt with a new social environment, and other specific symptoms.

Psychological problems such as social anxiety experienced by students often go unnoticed because they are considered as a process of adolescent development (Beesdo, Knappe, \& Pine, 2009; Veed, McGinley, \& Crockett, 2019). However, the impact of students who experiencing social anxiety cannot be ignored. Social anxiety in students is a form of psychological problem that tends to be hidden, but has an impact on the learning process and psychological well-being of students (Russell \& Topham, 2012). Students who are detected having high social anxiety level's are tend to experience disturbances in studies, social life, relationships with family, and this condition also affects their quality of life (Hakami et al., 2018). Anxiety disorders experienced by students were also found related to the tendency of students to withdraw from school (drop out) (Van Ameringen, Mancini, \& Farvolden, 2003). Social anxiety experienced by students is also significantly correlated with students' ability to make adjustments to the school environment and academic persistence, and has an effect on students' low academic achievement (Arjanggi \& Kusumaningsih, 2016; Brook \& Willoughby, 2015; Mazzone et al., 2007; Strahan, 2003).

The results of these studies strengthen empirical evidence that social anxiety is one of the student problems that requires special attention, because of its negative impact on students. Schools need to make efforts to minimize social anxiety experienced by students. This is in line with the current educational goals, which do not only focus on students' academic abilities, but also pay attention to their psychological aspects. Therefore, guidance and counseling as an integral part of the education process in Indonesian's schools has a role to help students achieve optimal development and complete personality in terms of personal, social, learning and career, as stated in Role of Indonesian Cultural and Educational Ministry, years of 2014, it is necessary to make efforts to minimize social anxiety experienced by students through guidance and counseling services.

One of the counseling models that can be used by BK teachers (school counselor) implementing counseling services in schools is the solution-focused brief counseling (SFBC) model. If the other counseling models only focused on the problem that experienced by student (students), SFBC helps student to find solutions that are currently available and focus on the future. The use of solution-focused brief counseling in school settings is recommended because it tends to use time more efficiently and effectively (De Jong \& Berg, 2013). The application of solution-focused brief counseling is also seen useful in school settings because school counselors are responsible for a large number of student but do not have sufficient time to conduct a long term counseling (Sklare, 2014). This accordance with the current needs of guidance and counseling services in Indonesia, where one BK teacher (counselor) guides a minimum of 150 students, so it is necessary to implement counseling services that have a shorter time but do not reduce their effectiveness. Solutionfocused brief counseling has also been shown to be effective in minimizing social anxiety experienced by individuals (Baijesh A.R, 2015; Pakan, 2015).

The implementation of guidance and counseling services in schools is currently still experiencing several obstacles. This obstacle is due to the limited availability of instrument that can assist BK teachers on giving service to students, especially related to minimize students' social anxiety. One form of instrument needed by $\mathrm{BK}$ teachers is a counseling guide. Counseling guides that are prepared based on a certain counseling model will assist BK teachers in providing guidance and counseling services as an effort to minimize social anxiety experienced by students. This study aims to report the results of the development of a counseling guidebook that can be used as an instrument that can assist BK teachers in implementing guidance and counseling services based on a solution-focused brief counseling model in an effort to minimize social anxiety experienced by students. 


\section{Method}

Research Design

The development procedure in this study was conducted by following the $4 \mathrm{D}$ development model consisting of four stages, namely define, design, develop, and disseminate (Thiagarajan, Dorothy, \& Melvyn, 1974). The piloting study (developmental testing) to evaluate the external validity with a measure of the effectiveness of the counseling model was conducted on experimental procedure with one group pretestposttest design.

\section{Research Subject}

This study involved 5 judges consisting of experts and practitioners in the field of guidance and counseling to assess the contents validity of the solution-focused brief counseling guidebook and 15 junior high school students as participants on the developmental testing.

\section{Instrumentation}

The data in this study consisted of data from expert judgment and the results of measuring students' social anxiety before and after counseling. Expert judgment data was obtained through a questionnaire consisting of 22 statements referring to 3 indicators of content validity, namely utility, feasibility, and accuracy. Data of students' social anxiety conditions were obtained through the Social anxiety scale for adolescence (SASA) instrument consisting of 11 statement items that have been adapted into Indonesian and have been tested valid for use (Apriliana \& Suranata, 2019).

\section{Data Analysis Procedure}

The results of expert 's judgment was analyzed to prove the content validity of the solution-focused brief counseling guidebook using the miracle question technique. The expert's judgment of each statement item was analyzed using the content validity ratio (CVR) approach by Lawshe (1975). After the CVR value is obtained, then the overall content validity value is determined using the content validity index (CVI) (Lawshe, 1975)

\section{Students Social Anxiety Measurement Data Analysis}

The results of students social anxiety measurement before and after attending counseling with a solutionfocused brief counseling guidebook were analyzed with Wilcoxon's signed rank. The used of non-parametric statistic is because the sample size was very small $(n=15)$ so the data distribution was not close to normal (Dantes, 2016). The analysis was carried out with the statistical program JASP version 0.13.

\section{Results and Discussion}

\section{Results of Content Validity Testing}

The results of the expert judgment were analyzed to determine the content validity of the solution-focused brief counseling guidebook. Based on the calculation of the CVR index, it shows that the solution-focused brief counseling guide developed in this study is valid based on the assessment items used, but there are still two items (number 18 on grammar and item number 22 on the appearance of the counseling guide) which have low index values. So it is necessary to re-examine the developed counseling guidebook, especially in the section related to these items.

Table 01. The Summary of Expert Judgement

\begin{tabular}{llllll}
\hline No & Statement & Relevant & $\begin{array}{l}\text { Not } \\
\text { Relevant }\end{array}$ & CVR & Category \\
\hline 1 & $\begin{array}{l}\text { The utility of counseling guidebook for BK teachers } \\
\text { in conducting solution-focused brief counseling } \\
\text { with the miracle question technique to minimize } \\
\text { students' social anxiety. }\end{array}$ & 0 & 1 & Accepted \\
2 & $\begin{array}{l}\text { The utility of counseling guidebook for students to } \\
\text { minimize social anxiety and overcome problems } \\
\text { experienced due to experiencing social anxiety. }\end{array}$ & 0 & 1 & Accepted \\
\hline \hline
\end{tabular}




\begin{tabular}{|c|c|c|c|c|c|}
\hline 3 & $\begin{array}{l}\text { The advantage of the counseling guidebook in } \\
\text { conducting solution-focused brief counseling with } \\
\text { the miracle question technique to minimize } \\
\text { students' social anxiety. }\end{array}$ & 5 & 0 & 1 & Accepted \\
\hline 4 & $\begin{array}{l}\text { The advantage of the counseling guidebook in } \\
\text { encouraging BK teachers to provide solution- } \\
\text { focused brief counseling guidance services with the } \\
\text { miracle question technique to minimize students' } \\
\text { social anxiety. }\end{array}$ & 5 & 0 & 1 & Accepted \\
\hline 5 & The accuracy of counseling guidebook contents & 5 & 0 & 1 & Accepted \\
\hline 6 & $\begin{array}{l}\text { The suitability of goals, method, materials and } \\
\text { techniques in solution-focused brief counseling } \\
\text { guidebook to the guidance and counseling } \\
\text { curriculum }\end{array}$ & 5 & 0 & 1 & Accepted \\
\hline 7 & $\begin{array}{l}\text { The suitability of goals, method, materials and } \\
\text { techniques used in solution-focused brief } \\
\text { counseling guidebook to minimize student's social } \\
\text { anxiety }\end{array}$ & 5 & 0 & 1 & Accepted \\
\hline 8 & $\begin{array}{l}\text { The accuracy of the language used in the solution- } \\
\text { focused brief counseling guidebook to the } \\
\text { characteristics of students. }\end{array}$ & 5 & 0 & 1 & Accepted \\
\hline 9 & $\begin{array}{l}\text { The contents and the substance clarity of solution- } \\
\text { focused brief counseling guidebook. }\end{array}$ & 5 & 0 & 1 & Accepted \\
\hline 10 & $\begin{array}{l}\text { The accuracy of counseling guidebook contents to } \\
\text { achieve the goals of minimize student's social } \\
\text { anxiety }\end{array}$ & 5 & 0 & 1 & Accepted \\
\hline 11 & $\begin{array}{l}\text { The accuracy of solution-focused brief counseling } \\
\text { techniques used in guidebook to the characteristic } \\
\text { of student's. }\end{array}$ & 5 & 0 & 1 & Accepted \\
\hline 12 & The accuracy of media/tool selection. & 5 & 0 & 1 & Accepted \\
\hline 13 & $\begin{array}{l}\text { The suitable of time allocation in each counseling } \\
\text { sessions }\end{array}$ & 5 & 0 & 1 & Accepted \\
\hline 14 & The clarity of counseling steps. & 5 & 0 & 1 & Accepted \\
\hline 15 & $\begin{array}{l}\text { The accuracy of evaluation procedure and } \\
\text { techniques. }\end{array}$ & 5 & 0 & 1 & Accepted \\
\hline 16 & $\begin{array}{l}\text { The practical use of solution-focused brief } \\
\text { counseling guidebook }\end{array}$ & 5 & 0 & 1 & Accepted \\
\hline 17 & $\begin{array}{l}\text { The effectiveness of the counseling guidebook } \\
\text { material in minimizing students' social anxiety. }\end{array}$ & 5 & 0 & 1 & Accepted \\
\hline 18 & The effectiveness of language and grammar. & 4 & 1 & 0,6 & $\begin{array}{l}\text { Accepted } \\
\text { with minor } \\
\text { revision }\end{array}$ \\
\hline 19 & $\begin{array}{l}\text { The practicality of the procedures or counseling } \\
\text { steps used to minimize students' social anxiety. }\end{array}$ & 5 & 0 & 1 & Accepted \\
\hline 20 & $\begin{array}{l}\text { The effectiveness of the time required to conduct } \\
\text { solution-focused brief counseling procedures and } \\
\text { techniques. }\end{array}$ & 5 & 0 & 1 & Accepted \\
\hline 21 & $\begin{array}{l}\text { The feasibility of social anxiety and solution- } \\
\text { focused brief counseling theoretical base used in } \\
\text { counseling guidebook }\end{array}$ & 5 & 0 & 1 & Accepted \\
\hline 22 & $\begin{array}{l}\text { The feasibility of solution-focused brif counseling } \\
\text { guidebook appearance. }\end{array}$ & 4 & 1 & 0,6 & $\begin{array}{l}\text { Accepted } \\
\text { with minor } \\
\text { revision }\end{array}$ \\
\hline \multicolumn{2}{|c|}{$\sum$ CVR } & & & 21,2 & \\
\hline
\end{tabular}


The content validity index of solution-focused brief counseling guidebook was calculated using the CVI formulation. According to Lawshe (1975), a score above 0.50 is a good content validity index, while a CVI score $>0.90$ to 1 is a special index. The results of the CVI analysis of the solution-focused brief counseling with the miracle question technique guidebook based on the expert judgment is 0.96 which is a special category. These results can be interpreted that based on expert judgment using a questionnaire consisting of 22 statements, the solution-focused brief counseling guidebook has a very good or special content validity index.

\section{The Results of Counseling Guidebook Effective Testing}

The limited trial for solution-focused brief counseling guidebook with the miracle question technique in this study was carried out through an experimental procedure with one group pretest-post test design. A limited trial was conducted to simulate the use of counseling guidebook by BK teacher to students, as well as to prove the effectiveness of using a solution-focused brief counseling guidebook to minimize student's social anxiety. The subjects in piloting study are 15 students of SMP Swastika Kapal, Badung, Bali, Indonesia. The subjects will be involved in a counseling by school counselor that following the procedures in solution-focused brief counseling with the miracle question techniques guidebook.

The implementation of the counseling guidebook limited trial was involved one BK teacher as a counselor. This procedure begins with conducting an assessment to obtain data on the social anxiety level of students before attending counseling. The initial assessment (pretest) was carried out using a social anxiety scale. The limited trial was conducted by BK teachers via online for 3 sessions by following the procedures in the solution-focused brief counseling with the miracle question technique guidebook. At the end of the counseling sessions, an assessment was carried out again to measure the level of social anxiety of students after attending counseling (post test).

Furthermore, the students' social anxiety scores that were measured at the pretest and post test were analyzed through the Wilcoxon's signed-rank test using the statistical program JASP 0.13 . The results of the analysis are as follows.

Table 02. The Results of Wilcoxon's Signed-rank Test

\begin{tabular}{llllllc}
\hline Sources & & W & df & $\mathbf{p}$ & $\begin{array}{l}\text { Hodges-Lehmann } \\
\text { Estimate }\end{array}$ & $\begin{array}{l}\text { Rank-Biserial } \\
\text { Correlation }\end{array}$ \\
\hline Pretest & - & $\begin{array}{l}\text { Post } \\
\text { test }\end{array}$ & 120.00 & & $<.001$ & 16.00 \\
\hline
\end{tabular}

Based on the results of the analysis, it was found that there were differences in students' social anxiety scores before attending counseling (pretest) and after attending counseling (post test). The location parameter (Hodges-Lehmann Estimate) indicates a median difference between the pretest and post test scores.

Table 03. Descriptive Statistic

\begin{tabular}{lllll}
\hline & N & Mean & SD & SE \\
\hline Social anxiety score before counseling & 15 & 38.13 & 6.47 & 1.67 \\
Social anxiety score after counseling & 15 & 22.40 & 2.85 & 0.74 \\
\hline
\end{tabular}

Based on the table above, it can be seen that there was a decrease in the average of social anxiety score in the pretest $(\mathrm{N}=15$, Mean $=38.13)$ compared to the average of social anxiety score in the pretest $(\mathrm{N}=15$, Mean $=22.40)$. The differences are illustrated in the following graph: 


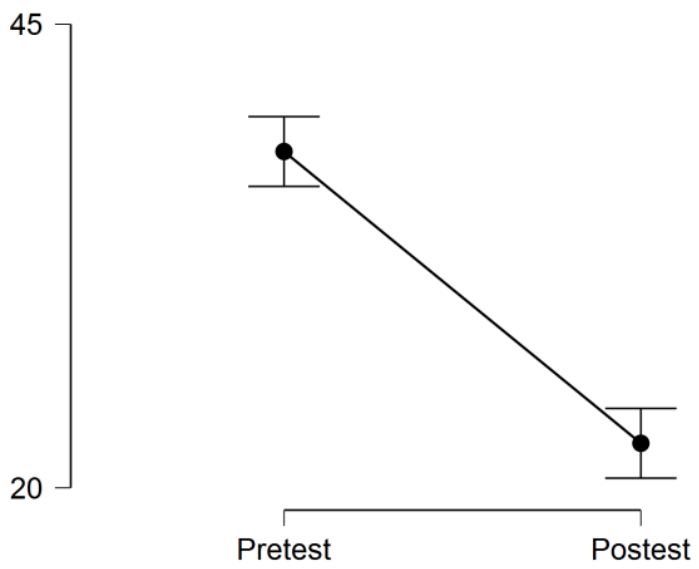

\section{Picture 01. Pretest and Post test Plot}

Based on the picture above, it can be seen that there was a decrease in the average score of student anxiety before counseling compared to score after attending counseling. The rank-biserial correlation (rB) can be considered as an effect size and is interpreted the same as the Pearson r correlation (Goss-Sampson, 2019), so based on the results of the analysis above, it is known that the effect size value is 1.00 which indicates a large effect size. Based on the results of the analysis, it was concluded that the solution-focused brief counseling with the miracle question technique guidebook reduced the average score of students' social anxiety significantly and had great effectiveness in minimizing students' social anxiety.

\section{Discussion}

This research produces a product in the form of a solution-focused brief counseling guidebook with a miracle question technique that can be used as an instrument for BK teachers in an effort to minimize social anxiety experienced by students. The initial product (prototype) of the counseling guidebook then tested to prove the content validity. The content validity testing is important to do in the process of developing counseling guidance guidebook, so before being used as an instrument to help students through counseling services, the counseling guidebook has met the theoretical feasibility (Naraswari, Dantes, \& Suranata, 2020).

The results of content validity testing showed that the solution-focused brief counseling with the miracle question technique guidebook developed in this study had a special content validity index. Based on the 22 items used, the solution-focused brief counseling guidebook has good validity for all of these items, although there are 2 items that need to be re-examined and used as a reference to perfect this counseling guide. There are some written inputs given by judges, including improvements to some sentences to make them more effective and adjustments to some pictures to make them relevant to the contents of the counseling guidebook.

The solution-focused brief counseling guidebook that have met the theoretical validity through expert judgment, then used by school counselor to conducting counseling in limited trial. The limited trial of solution-focused brief counseling guidebook in this study was carried out through an experimental procedure of one group pretest-post test design and involving 15 students as students who will attend solution-focused brief counseling with the miracle question technique. The results of the analysis showed that there was a significant decrease between students' social anxiety scores before attending counseling and after attending counseling. Statistical analysis also shows that the solution-focused brief counseling guidebook with the miracle question technique has great effectiveness in minimizing students' social anxiety.

Based on the results of the research that has been described, it was found that the solution-focused brief counseling guidebook with the miracle question technique developed in this study has met the theoretical feasibility criteria, and has proven its effectiveness in minimizing social anxiety experienced by students. .

The results of this study are relevant to the need for developing guidance and counseling service instruments in schools which as described in Role of Indonesian Cultural Education Ministry, Number 111 of years 2014 is have a purpose to help students achieve optimal development, both in personal, social, learning, and career aspects. 
The availability of counseling guidebook that have met the theoretical and empirical eligibility criteria will help BK teachers as guidance and counseling practitioners to provide more professional guidance and counseling services. This research is in line with several previous studies related to the development of counseling guides, including research by Bancin, Mudjiran, \& Rusdinal, 2017; Swandevi, Suranata, \& Dharsana (2020), and Ernayanti, Dantes, \& Suranata (2020) who have found that the development of guidance books/counseling modules that have been tested theoretically and empirically can be used as an instrument to support the implementation of guidance and counseling services in schools.

The results of this study have implications for the implementation of guidance and counseling services in schools, especially as an effort to minimize social anxiety experienced by students. The solution-focused brief counseling model adapted in this counseling guidebook is a counseling model that has been tested for its effectiveness in intervening various psychological aspects. The use of solution-focused brief counseling as an effective intervention model in various fields has been described in a study by Gingerich \& Peterson, (2015). Other research results by Haron, Abu Bakar, \& Suranata (2020) suggested that solution-focused brief counseling can be applied in various settings, especially those that require a fast but still effective counseling process, such as the implementation of counseling services in schools. Especially in minimizing anxiety, solution-focused brief counseling has also been proven to be effective (Baijesh A.R, 2015; Pakan, 2015). The effectiveness testing of the solution-focused brief counseling guidebook developed in this study is still limited, because its only used in counseling to minimize student's social anxiety. However, it is possible that the counseling guidebook will be effectively used in intervening other psychological aspect. Therefore, further studies are need to reveal the effectiveness of using the solution-focused brief counseling guidebook in a wider population.

\section{Conclusion}

This research and development has produced a solution-focused brief counseling with the miracle question technique guidebook. Based on the results of expert judgments, the counseling guidebook has a content validity index of 0,96 which is a special content validity category. The limited trial of the counseling guidebook that was carried out through an experimental procedure showed that there was a decrease in the average score of student's social anxiety after attending solution-focused brief counseling with miracle question technique based on the counseling guidebook developed in this study. These results indicate that the solution-focused brief counseling guidebook has been proven effective in minimizing student's social anxiety. Based on the findings in this study, the solution-focused brief counseling guidebook is suggested to be used as an instrument by school counselor, especially as an effort to minimize students social anxiety. This research is still conducted in limited subjects, further research is needed on the use if solution-focused brief counseling guidebook in intervening another psychological aspect and wider populations.

\section{Acknowledgment}

I would like to thank Prof. Dr. Nyoman Dantes as the one supervisor who has provided guidance, direction and advice in completing this research and Mrs. Prof. Dr. Ni Ketut Suarni, M.S., Kons. As a two mentor who has provided guidance, direction and motivation in completing research on the development of innovative creative character instruments in high school /vocational school in Denpasar.

\section{References}

Apriliana, A., \& Suranata, K. (2019). A confirmatory factor analysis of social anxiety scale for adolescence in Indonesian form. Konselor, 8(3), 98-103. https://doi.org/10.24036/0201983105819-0-00

Arjanggi, R., \& Kusumaningsih, L. P. S. (2016). The Correlation between Social Anxiety and Academic Adjustment among Freshmen. Procedia - Social and Behavioral Sciences, 219, 104-107. https://doi.org/10.1016/j.sbspro.2016.04.049

Baijesh A.R. (2015). Solution Focused Brief Therapy for Social Anxiety Disorder- A Pilot Study. International Journal of Psychology and Education, 2(7), 8-12. 
Bancin, I. K., Mudjiran, \& Rusdinal. (2017). Pengembangan Modul Bimbingan dan Konseling Tentang Regulasi Diri Siswa Dalam Hubungan Sosial. Jurnal Penelitian Bimbingan Dan Konseling, 1(5), 9199.

Beesdo, K., Knappe, S., \& Pine, D. S. (2009). Anxiety and Anxiety Disorders in Children and Adolescents: Developmental Issues and Implications for DSM-V. Psychiatric Clinics of North America, 32(3), 483524. https://doi.org/10.1016/j.psc.2009.06.002

Brook, C. A., \& Willoughby, T. (2015). The Social Ties That Bind: Social Anxiety and Academic Achievement Across the University Years. Journal of Youth and Adolescence, 44(5), 1139-1152. https://doi.org/10.1007/s10964-015-0262-8

Dantes, N. (2016). Statistika Nonparametrik. Singaraja: Undiksha Press.

De Jong, P., \& Berg, K. I. (2013). Interviewing for Solution (4th ed.). United Kingdom: Cengage Learning.

Ernayanti, N. M. D., Dantes, N., \& Suranata, K. (2020). Cognitive Behavior Counseling to Improve Responsibility Attitudes: A Development of Guidebooks. Bisma The Journal of Counseling, 4(2).

Gingerich, W. J., \& Peterson, L. T. (2015). Effectiveness of Solution-Focused Brief Therapy : A Systematic Qualitative Review of Controlled Outcome Studies, 23(3), 266-283. https://doi.org/10.1177/1049731512470859

Goss-Sampson, M. A. (2019). Statistical Analysis in JASP: A Guide for Students (2nd ed.). University of Greenwich.

Hakami, R. M., Mahfouz, M. S., Adawi, A. M., Mahha, A. J., Athathi, A. J., Daghreeri, H. H., ... Arishi, N. A. (2018). Social anxiety disorder and its impact in undergraduate students at Jazan University, Saudi Arabia. Mental Illness, 9(2). https://doi.org/10.4081/mi.2017.7274

Haron, R. A., Abu Bakar, A. Y., \& Suranata, K. (2020). Application of Solution-Focused Brief Therapy (SFBT) to Help Clients with Anxiety Issues. Bisma The Journal of Counseling, 4(1), 16. https://doi.org/10.23887/bisma.v4i1.24709

Lawshe, C. H. (1975). a Quantitative Approach To Content Validity. Personnel Psychology, 28(4), 563-575. https://doi.org/10.1111/j.1744-6570.1975.tb01393.x

Mazzone, L., Ducci, F., Scoto, M. C., Passaniti, E., D’Arrigo, V. G., \& Vitiello, B. (2007). The role of anxiety symptoms in school performance in a community sample of children and adolescents. BMC Public Health, 7, 1-6. https://doi.org/10.1186/1471-2458-7-347

Mitchell, M., MacInnes, D., \& Morrison, I. (2008). Student wellbeing study. New Zealand.

Naraswari, I., Dantes, N., \& Suranata, K. (2020). Pengembangan Buku Panduan Konseling Cognitive Behavior Untk Meningkatkan Self Esteem Siswa SMA: Studi Analisis Validitas Teoretik. Indonesian Journal of $\quad$..., $9(1) . \quad$ Retrieved from https://journal.unnes.ac.id/sju/index.php/jbk/article/view/38806

Pakan, J. A. (2015). Counseling to Reduce Stress and Anxiety: A Mixed Methods Study. Counselor Education Capstone.

Permendikbud nomer 111 tahun 2014. Peraturan Menteri Pendidikan dan Kebudayaan Republik Indonesia tentang Bimbingan dan Konseling pada Pendidikan Dasar dan Pendidikan Menengah (2014). Indonesia: Kementrian Pendidikan dan Kebudayaan Republik Indonesia. Retrieved from simpuh.kemenag.co.id

Russell, G., \& Topham, P. (2012). The impact of social anxiety on student learning and well-being in higher education. Journal of Mental Health, 21(4), 375-385. https://doi.org/10.3109/09638237.2012.694505

Sklare, G. B. (2014). Brief Counseling That Works: A Solution-Focused Therapy Approach for School Counselors and Other Mental Health Professionals (3rd ed.). London: Corwin.

Strahan, E. Y. (2003). The effects of social anxiety and social skills on academic performance. Personality and Individual Differences, 34(2), 347-366. https://doi.org/10.1016/S0191-8869(02)00049-1

Swandevi, N. K. A., Suranata, K., \& Dharsana, I. K. (2020). Development of The Solution Focused Brief Counseling (SFBC) to Improve The Autonomy of Vocational School Students. Bisma The Journal of Counseling, 42 .

Thiagarajan, S., Dorothy, S. S., \& Melvyn, I. S. (1974). Instructional development for training teachers of exceptional children: A sourcebook. Minnesota: Leadership Training Institute/Special Education, University of Minnesota. https://doi.org/10.1016/0022-4405(76)90066-2

Untari, R. T., Bahri, S., \& Fajriani. (2017). Pengaruh Harga Diri Terhadap Kecemasan Sosial Remaja Pada Siswa di SMA Negeri Banda Aceh. Jurnal Ilmiah Mahasiswa Bimbingan Dan Konseling, 2(2), 1-10.

Bisma The Journal Of Counseling, Open Access, https://ejournal.undiksha.ac.id/index.php/bisma 
Van Ameringen, M., Mancini, C., \& Farvolden, P. (2003). The impact of anxiety disorders on educational achievement. Journal of Anxiety Disorders, 17(5), 561-571. https://doi.org/10.1016/S08876185(02)00228-1

Veed, G. J., McGinley, M., \& Crockett, L. J. (2019). Friendship network influence on the development of internalizing symptoms during adolescence. Journal of Applied Developmental Psychology, 60(September 2018), 157-165. https://doi.org/10.1016/j.appdev.2018.09.002

Vriends, N., Pfaltz, M. C., Novianti, P., \& Hadiyono, J. (2013). Taijin Kyofusho and Social Anxiety and Their Clinical Relevance in Indonesia and Switzerland. Frontiers in Psychology, 4(February), 1-9. https://doi.org/10.3389/fpsyg.2013.00003

Article Information (Supplementary)

\section{Conflict of Interest Disclosures: \\ The authors declare that they have no significant competing financial, professional or personal interests that might have influenced the performance or presentation of the work described in this manuscript.}

Copyrights Holder: <purwani > <2021> First Publication Right: BISMA The Journal of Counseling 